UDK 78:81’373.46

Prethodno priopćenje

Rukopis primljen 16. VII. 2018.

Prihvaćen za tisak 10. XI. 2018.

\title{
Anita Jóri
}

Berlin University of the Arts

a.jori@medienhaus.udk-berlin.de

\section{ON THE TERMINOLOGY OF ELECTRONIC (DANCE) MUSIC}

Due to rapid technological developments, the terminology of electronic (dance) music is constantly changing. This also causes challenges for the discourse community of electronic dance music in the use of different technical terms.

This paper gives a general overview on the subject as it is a pioneer investigation of research. Firstly, it summarises the characteristics of the discourse community's language use. Later, it highlights the different types of technical terms used by the terminology users. For this, tech terms of a web discussion forum are analysed in detail.

The article also describes some of the challenges in using these technical terms by taking different examples from three languages: English, German, and Hungarian. Moreover, phenomena such as the lack of standardisation, norms, and music glossaries and the influences from other terminologies (e.g. classical music, informatics, mathematics, physics) are also included in the study.

After presenting the most striking issues, the paper also proposes a possible practical solution to the phenomena in question: it outlines a plan for creating a wiki on the technical terms of electronic (dance) music.

\section{Introduction}

\subsection{The discourse community of electronic dance music}

Electronic dance music has a highly diverse profile in terms of its aesthetics and audiences. Research on its communities has been initiated by scholars in the fields of sociology, cultural studies, public health research, gender studies, and so forth. However, research on the actual language use of the related communities is surprisingly uncommon. 
In order to introduce the topic of the the discourse community of electronic dance music, I must first summarise my earlier research results. In my PhD thesis, I proposed a model of the discourse community of electronic dance music that observes the participants of the community as individuals who are interested in electronic dance music, and willing to communicate on such topics. This means that not only musicians and fans are part of the community, but also people who, for example, work within the scene, such as graphic designers (designing flyers, cover art, etc.), customer care agents at related companies (software/hardware companies producing equipment/instruments for electronic music production), music managers, etc. Therefore, in this view, the community was built up by the discourse and the language use (Jóri 2016). Other fields such as sociology or cultural studies focus on these communities' behaviour from other perspectives (e.g. how these individuals' identities are influenced by the community and the music). Hence, my research shifts its interest from such analyses to the actual language use of these communities.

From John M. Swales's (1990) perspective, the following points can be stated about the discourse community (henceforth DC) of electronic dance music (henceforth EDM):

"1. It has a common public goal: communication on electronic dance music and related topics. 2. It has mechanisms of intercommunication: e.g. emails, forum conversations, phone calls, etc. 3 . These mechanisms were set up to provide information about electronic dance music. 4. It has more genres in the communicative furtherance, e.g. Internet genres (blogs, forums, web-pages, etc.) and multimodal texts (flyers, posters, album cover art, etc.). 5. It has a specific lexis (e.g. pattern, MIDI, loop, etc.). 6. Its common knowledge is based on the topic of electronic dance music and the members have different levels of knowledge" (Jóri 2012).

From these points, the 5th and 6th will be interesting for this paper. We will see different examples for this special lexis and also for the community members' specialised knowledge. The special lexis or terms are "terminological units which most efficiently manipulate the knowledge of a particular subject" (Cabré 2003: 182) and they are also "units of special meaning" (190).

Moreover, we can add that the community members of the DC of EDM take part in specialised discourses and communication. This communication is seen here 
as a set of options inside a single schema and not as a different type of communication (Cabré 2003). According to Cabré (2003), it differs from general communication in two ways: 1) in the type of oral or written text it produces; and 2) in the use of a specific terminology.

Therefore, from the different terminological theories or schools, this study takes the communicative theory of terminology (Cabré 1999; 2009) as well as Temmerman's (2000) socio-cognitive terminology into account.

\subsection{Discourse analysis}

Since my earlier research was and still is a pioneer in the field, the widest possible range of perspectives had to be integrated. Therefore, discourse analytical methods - namely, computer-mediated discourse analysis - were applied in order to analyse the collected data. The linguistic data included web 2.0 usergenerated content, in other words, online discourse sources such as posts of web discussion forums, blogs, Facebook groups and user comments on classical websites. I chose this type of data for my research because firstly, it is easy to access, secondly, it is close to the everyday communicational situations and style of language use. Also, by taking linguistic data from web sources in the Web 2.0 era, we can reconstruct the characteristics of the written (and partly spoken) discourses of a discourse community. Of course, we have to keep in mind that these sources have the general characteristics of the language use on the Internet (see e.g. Crystal 2001).

Based on Susan C. Herring's (2004) methodology model of computer-mediated discourse analysis, I analysed the four domains of language separately: structure, meaning, interaction management and social phenomena. Each domain examined different linguistic phenomena and issues and uses different analytical methods, which are summarised in the following table. 
Table 1. Analysed phenomena, explored issues and their analytical methods ${ }^{1}$

\begin{tabular}{|c|c|c|c|}
\hline Language domains & Pnenomena type & Explorea issues & Analyucal metnod \\
\hline \multirow{4}{*}{ Structure and meaning } & technical terms & common ground; knowledge & $\begin{array}{l}\text { Terminology } \\
\text { studies }\end{array}$ \\
\hline & specific community reference words & refernce to group: in- and out-group language & Content analysis \\
\hline & personal pronouns & $\begin{array}{l}\text { "T"/ "we" vs. "they" = signifiers of individual vs. } \\
\text { social identity }\end{array}$ & $\begin{array}{l}\text { Content analysis } \\
\text { and descriptive } \\
\text { statistics }\end{array}$ \\
\hline & compensatory strategies & $\begin{array}{l}\text { expressions with other tools (not text): their } \\
\text { community markers }\end{array}$ & $\begin{array}{l}\text { Multimodal } \\
\text { discourse analysis }\end{array}$ \\
\hline \multirow[b]{2}{*}{ Interaction management } & concern structures & $\begin{array}{l}\text { signifier of respecting the other members; } \\
\text { initiation response }\end{array}$ & $\begin{array}{l}\text { Conversation } \\
\text { analysis }\end{array}$ \\
\hline & participation & $\begin{array}{l}\text { special roles in a community; power relations and } \\
\text { their roles in community construction and } \\
\text { sustaining }\end{array}$ & $\begin{array}{l}\text { Descriptive } \\
\text { statistics and } \\
\text { conversation } \\
\text { analysis }\end{array}$ \\
\hline Social phenomena & information exchanges & $\begin{array}{l}\text { way of showing interest in one another; showing } \\
\text { mutual influence; sense of belonging }\end{array}$ & $\begin{array}{l}\text { Conversation } \\
\text { analysis }\end{array}$ \\
\hline
\end{tabular}

In this paper, we will take a closer look at the analysis of the technical terms within the domain of structure and meaning, shown in the second row in the table above. These technical terms are group-specific and signifiers of the discourse community's common ground.

\section{Research aims and methods}

This paper aims to give a general overview of the terminology of electronic (dance) music as a strong recognition of the language use of the above-described discourse community. For this, the different types of technical terms from online discourse sources will be analysed with the help of terminology studies.

Moreover, by comparing the existing glossaries on the subject in three languages (English, German, Hungarian), the aim is to reflect on phenomena such as the lack of standardisation and translation problems.

Finally, the paper will also propose possible practical solutions to these phenomena in question: it outlines a planned wiki on the technical terms of electronic (dance) music.

\footnotetext{
From Jóri 2016.
} 


\section{The terminology of electronic (dance) music}

\subsection{Electronic (dance) music}

Before I analyse the use of technical terms within the discourse community in question, I must answer why dance was put into brackets in the title of this paper.

Historically, there has always been a huge discussion around the umbrella term electronic dance music among scholars and practitioners, and the terms electronic music and electronic dance music have taken on many different and also misleading meanings.

The term electronic formally denotes applications of the transistor and became popular in the mid-twentieth century (Collins, Schedel and Wilson 2013). Originally, electronic dance music (EDM) was adopted by the U.S. music industry and press to describe commercial electronic music in the late 1990s and early 2000s (Jóri 2016). Therefore, it has been criticised by musicians and other participants of "underground" music scenes. However, in academic studies ${ }^{2}$ it is now used as an umbrella term for many electronic music genres born after the late 1970s to early 1980s. Some researchers have raised their voices against this umbrella term, first, because of its history in the music industry; second, because it could be interpreted in a way that only includes genres that are intended for dancing (e.g. McLeod [2001] introduces electronic/dance music with a slash), which is not entirely true since EDM has many experimental genres - with their noise elements - without aiming to make people move at all.

To sum up, we can state that electronic music is the most general genre name, including all historical periods (from the end of World War II) and electronic dance music is one of the large categories or streams within it, starting in the late 1970s and early 1980s. This case also presents an example of the lack of standardisation in using such important terms.

So, since the terminology of EDM also includes terms from earlier periods and other streams of electronic music, I decided to put dance in brackets.

\footnotetext{
2 See e.g. the peer-reviewed, open-access e-journal Dancecult, dedicated to the study of electronic dance music culture: https://dj.dancecult.net/index.php/dancecult (accessed 18 May 2018).
} 


\subsection{The classification scheme of the technical terms}

One can find many different categorisation systems of technical terms in literature. They are mostly classified by their forms, functions, meanings or origins (Cabré 2003). For the present research, Fóris's classification (2010: 434) ${ }^{3}$ was applied, which is based on the forms and concepts (function) and communication (the common language-based intelligibility) of the terms. She differentiates three main categories as follows: $\left.{ }^{4} 1\right)$ real technical terms that cannot be understood and identified by an average speaker of a language. Their forms and concepts differ from the other terms in the vernacular. Fóris (2010) divides this group into two parts: 1a) concrete technical terms and 1b) lexical technical terms. The forms and concepts of the concrete technical terms are not known in the vernacular at all; only the users of the technical language can identify them. On the other hand, the meanings of the lexical technical terms are known, but with other forms in the vernacular. The second category is the 2) 'semantic variant' technical terms which have forms from the vernacular, but their concepts are different in the technical language. Finally, 3) the vernacular technical terms where the form and concept are the same in the vernacular, but they still belong to the technical language.

Apart from Fóris's classification scheme (2010), it is also important to look at the linguistic origins of these technical terms. Namely, I was interested in the units borrowed from other subject fields, which will be shown within the analyses.

To present some examples for the types of terminology introduced above, linguistic data was taken from a web discussion forum, 'Gearslutz'.

\subsection{Gearslutz}

Founded in 2002, Gearslutz is a web discussion forum for audio recording and production techniques. ${ }^{5}$ It deals with music production on different levels, from amateur to professional. Thus its users take part in a specialised communication (or discourse) on such topics.

The article introduces the sociolinguistic approach within LSP research.

These category names are translated from the Hungarian article into English by the author of this text.

https://www.gearslutz.com (accessed 1 May 2018). 
I analysed the thread 'Lets talk samplers!' from the sub-forum 'Electronic Music Instruments \& Electronic Music Production' (the same example was taken in Jóri 2016, but there I was rather focusing on the discourse analytical perspectives, and the terminological aspects were only mentioned and not analysed in detail). The thread focuses on different types of samplers. These are electronic or digital instruments using samples of real instrument sounds, recorded songs or other sounds. The opening post was on 18 September 2007 and has 449 posts up until November 2016. I analysed only the first 60 posts because they include adequate amount of technical terms to introduce the above-clarified types of terminology. To organise the data, I used the concordance programs AntConc (3.5.7) and WordStatix.

The analysed posts consist of 4624 word tokens and 1233 word types. From these 1233 word types, I identified 90 technical terms: ${ }^{7}$ mostly nouns but there are three verbs and also one adjective among them. Moreover, 27 additional word types were brand names of different music production and computation equipment which are also known only to the participants of the special communication, so they are signifiers of the common ground and knowledge of the discourse community.

As mentioned, most of the technical terms are related to music production and especially to samplers. In order to identify and categorise these terms, I used Oxford Dictionaries ${ }^{8}$ as a reference point for vernacular English and different online glossaries ${ }^{9}$ of electronic dance music and technologies.

If we use the classification of technical terms described above, the following examples can be presented: ${ }^{10}$ 1a) concrete technical terms are, e.g.: EQ, hardware, MIDI (Musical Instrument Digital Interface), phaser, SCSI (Small Computer System Interface), sequencer, etc.; 1b) lexical technical terms could not be identified within the 90 terms. 2) Semantic variant technical terms are, e.g.; channel, circuit, compressor, emulation, envelope, emulator, loop, modulation, sampler,

\footnotetext{
6 https://www.gearslutz.com/board/electronic-music-instruments-and-electronic-music-production/145494 -lets-talk-samplers.html (accessed 5 May 2018). The thread has been analysed in my PhD thesis, too. However, this time we take a closer look at the terminology of it, and not the discourse as a whole.

7 Of course, it can be that other coders would identify more or less of them.

8 https://en.oxforddictionaries.com (accessed 6 May 2018).

9 More about them later.

${ }_{10}$ Only selected examples are taken here.
} 
etc. If we take the first example, channel, we will find in Oxford Dictionaries ${ }^{11}$ definitions of water, radio and TV channels, communication distribution, and only the fourth entry mentions the audio channel as being part of the terminology of 'electronics' and not the vernacular. Finally, the following examples can be taken as 3) vernacular technical terms: cable, computer, DJ, laptop, monitor, record, speaker, vocal, etc. These are well known terms in the vernacular, but still part of the terminology in question.

Electronic music production has a strong relation to computation and audio and sound recording technologies. Therefore, we can identify many borrowed units from other subject fields, such as physics (e.g. circuit, compression, compressor, resistor), information technology or computing (e.g. expansion, hardware, interface, memory), and electronic technology (e.g. adapter, cable, envelope). Here I must also mention that the recording (and electronic music) technologies, as Rodgers (2010: 6) puts, "emerged directly from wartime expenditures or were funded for their potential military applications." 12 Then later during the Cold War, electronic sounds became even more popular, partly due to the space age and atomic research (Rodgers 2010). Therefore, the terminology is highly militaristic (e.g. bang, command, controller, executes, trigger, etc. [examples from Rodgers 2010: 7]). A good example would be one of the above-mentioned concrete technical terms, hardware. The first definition of hardware in Oxford Dictionaries is "tools, machinery, and other durable equipment" and its example is 'high-tech military hardware'. ${ }^{13}$ This phenomenon can, of course, open up a discussion from the perspective of gender studies, which I will not include in this paper, but I think it is an important issue for people wanting to broaden their knowledge on the terminology of electronic (dance) music.

I also realised in the analysis of Gearslutz, that in order to break up the technologically driven conversation, the users of the web discussion forum often turned to figurative language in the form of different adjectives, in order to improve communication and describe the samplers in question and their sounds. These adjectives have a highly metaphoric character, which is a common phenomenon in describing music and sound. They are metaphoric linguistic expressions (or

11 https://en.oxforddictionaries.com/definition/channel (accessed 21 May 2018).

12 World War I and II.

13 https://en.oxforddictionaries.com/definition/hardware (accessed 20 May 2018). 
linguistic metaphors): sick filters; Ensoniq ASR10: dirty and bitty; EMU E4: Fat and analogue'y; Emu: (...) logical, ergonomic, clean and punchy sounding; very powerful digital filters; E2/EMAX are very dirty and fat, E3 is cleaner and smoother; ensoniq [is] more gritty; NI Kontakt, Mach5, Digis one, Es24, Halion are all ultra bloated; The roland sample cd series are also killer!. In these cases, the target domain is always the complex concept of music or sound (produced by the machines described). It is not a surprising phenomenon, since talking about the complexity of music and sound can be very difficult in general; we thus often turn to metaphors or metaphorical expressions in order to express our thoughts on the subject (see more in Jóri 2015). These metaphoric linguistic expressions can be related to different conceptual metaphors, e.g. if we take the examples of dirty, bitty and gritty, they can be references to the conceptual metaphor MUSIC IS A FACTORY.

These examples also underlie the ideas of Sociocognitive Terminology, which based on Lakoff's (1987) and Johnson's (1987) ideas - "considers our knowledge about the world of science and technology as experimental" (Temmerman 2000: 61 ) and the world is partly in the human mind. Therefore, in order to understand language, we also have to understand the world. According to Johnson (1987), what we know and understand about the world is embodied; partly based on our sensory perception (Temmerman 2000). The other part is the result of our reasoning that comes from that sensory perception and the transfer of others' ideas (Temmerman 2000).

In this sense, these examples of metaphoric linguistic expressions clearly represent the units of understanding of the complex phenomena of electronic dance music production, which is highly related to computation and information technology.

\subsection{Questions of standardisation}

In the second half of the analysis, I will focus on the questions of standardisation.

The terminology of electronic dance music has not been standardised professionally by scholars of terminography in any language yet. In order to take a closer look at the phenomenon, I conducted research on the existing glossaries of the subject in three languages: English, German and Hungarian. These three 
languages have very different positions in terms of their character and they also play different socio-political roles: English is a world-wide recognised lingua franca, German is a relatively widely spoken language in Europe and Hungarian is the least spoken from the three.

\subsubsection{Existing glossaries}

In English, we find several existing glossaries of electronic (dance) music and recording technologies online and offline. For the printed versions, a very early example could be Richard Dobson's "A Dictionary of Electronic and Computer Music Technology. Instruments, Terms, Techniques," published in 1992. It has never been updated since then, which also presents one of the disadvantages of these printed glossaries: the newest terminology is completely missed in them. On the other hand, they are still a good reference for further works.

A second early example is "Tech Terms. A Practical dictionary for Audio and Music Production" by George Petersen and Steve Oppenheimer, published in 1993. If we compare it to Dobson's work, we can state that this tiny publication with its 50 pages is a less professionally written collection of terms on the subject.

A contemporary example is "Good Musician: The biggest glossary of all music production words, acoustics terms, EDM genres, audio engineering terminology, recording vocabulary, and music theory definitions" by Shadow Producers, which includes terms from subcultures as well - for example, the meaning of music genres - not only from the music production. However, the entries are extremely short and vague.

From the online glossaries, I would like to highlight just one, by Hugh Robjohns and Paul White, collected for the magazine "Sound On Sound." ${ }^{14}$ It is a detailed and widespread collection of 642 entries at present. ${ }^{15}$ Its users are also encouraged to send to the editors those terms that have not been explained on the list.

In German, there are many printed glossaries as well. One of the earliest lexicons is "Das Lexikon der elektronischen Musik" by Herbert Eimert and Hans Ulrich Humpert, published in 1973. Today it is of importance from a historical

\footnotetext{
14 https://www.soundonsound.com/sound-advice/glossary-technical-terms (accessed 10 May 2018).

15 Summer 2018.
} 
point of view: it illustrates the 1970s discourse on the German 'elektronische Musik'. Another early example is "Electronic Music ABC" by Babs Ahland, Jacky Dreksler and Quirin Härle, published in 1988. It is a pocket lexicon, but quite detailed. The entries are explained shortly, but there are around 2000 terms included in it. Also, another early publication from 1987 - republished ten years later in 1997 - is the "Lexikon Musikelektronik" by Bernd Enders.

Online we can find a couple of German glossaries as well, but most of them have a very short list of entries. Here I would like to name only one example: "Begriffe der elektronischen Musiksynthese"16 on Heiko Plate's website, who is well known for his own programs and articles on MIDI technology. The entries are only short, but one of the advantages of the list of terms is that it has a hyperlink function. So if the users click on other related technical terms within an entry, they can easily read and find another one. If we take a closer look at the list of terms, we can see that most of the terms are English, e.g. envelope, event, filter, pitch wheel, release, track. However, we also find translated forms in German: Frequenz, Hochpassfilter (from high-pass filter), sedezimal, etc. Of course, we do not know from this list if these terms are used in the same way as by other practitioners. For this, we would need another deeper analysis on this issue.

In Hungarian, the list will be very short: There are no printed glossaries on the subject and online we find also only a few examples with a couple of entries. One of them is a selection of terms for DJs. ${ }^{17}$ On this list we find many English terms, such as fader, hi-fi, loop, remix, scratch. At the same time, there are some translated into Hungarian: duplázás 'doubling', mixelés 'mixing', színuszhang 'sinus sound'. In my earlier research on Hungarian web discussion forums (Jóri 2011; 2013a), ${ }^{18}$ I realised that due to the lack of standardisation in Hungarian, there are misunderstandings in professional communication. This problem comes from the fact that sometimes the language users use one technical term in two or even three forms. It is many due to the tendency that these terms are often used in the original form in English (e.g. loop) or in a phonetically adjusted version in Hungarian (e.g. sequencer $=$ szekvenszer, crossfader $=$ krosszféder,

\footnotetext{
16 http://www.heikoplate.de/mambo/index.php?option=com_content\&task=view\&id=454\&Itemid=63 (accessed 10 May 2018).

17 http://dj-info.mindenkilapja.hu/html/18097739/render/dj-szotar (accessed 15 May 2018).

18 I analysed the language use of http://www.drumandbass.hu/, http://breakbeat.hu/forum/ (that works today on Facebook under https://www.facebook.com/breakbeathu/) and http://minimalmusic.hu/forum (which does not work anymore).
} 
oscillator $=$ oszcillátor, clip $=k$ lipp, set $=s z e t t)$; or in a translated Hungarian form (e.g. csillapitás 'decay', minta 'pattern'). A good example for using three different forms for the same definition is routing, jelútválasztó, jelvezetés from the Hungarian translation of the handbook (Delaney 2009) of the music making software Ableton Live. This example will bring us to the question of translation.

But before we move to this topic, to summarise the actual situation of the glossaries and lexicons of electronic music, we can state that first of all, they are seldom and the existing ones are mainly not professional contributions in terms of terminographical work. Secondly, the printed versions are not up-to-date due to the rapid changes and developments in technology. This can bring us to the conclusion that it is unnecessary to create a glossary (or lexicon, or dictionary) in a printed version. A good example could be the company Ableton's strategy. ${ }^{19}$ Since their software always has new versions (at the moment it has reached version 10), the company decided not to print out the handbook, but instead it is available online. ${ }^{20}$

\subsubsection{Translation problems}

In the above-mentioned handbook by Delaney (2009), the Hungarian translator might have had serious problems with the translation of the original English text, because the Hungarian and English conceptual systems are different. Although translation is possible at the level of words, it is more difficult in conceptual terms (Fóris 2005). The translator uses three terms, routing, jelútválasztó, jelvezetés alternately, probably in order to avoid duplication. However, the translation of routing to both Hungarian forms may be misleading for a novice composer because of the unambiguous occurrence of the term. It is indispensable to apply exact terms with one form and meaning in the technical language (Jóri 2013b).

Familiar problems occur in German translations - even though German is structurally not as far from English as Hungarian - due to the overload of English loanwords. As we can read in the aims of "Lexikon Musikelektronik" (2nd ed., 1997), due to fast technological developments, there are continually new English technical terms in the field, which have not sprung from practical musical

\footnotetext{
19 https://www.ableton.com/ (accessed 15 May 2018).

20 https://www.ableton.com/en/manual/welcome-to-live/ (accessed 11 May 2018).
} 
applications, but mainly from a technical view of functional concepts. It then often becomes impossible to understand the meaning of the terms. ${ }^{21}$ Moreover, the author writes that "the aim of this dictionary is therefore to explain the terms used to translate English words and specify their concrete pronunciation." ${ }^{22}$ So we can state that the editor of this glossary tried to raise awareness about "terminographical and terminological issues" in the translation process.

At this point, we can ask ourselves whether it is at all meaningful to translate these English terms into other languages if the musicians and other practitioners use the English original for their work? This question can be answered, of course, only by the people who use this technical language for their communication at work. However, in order to outline a possible answer for such questions, the next part of the paper will focus on one of the solutions.

\section{A Wiki might help?}

We have seen many different issues about using the technical language of electronic dance music in English, German and Hungarian. We have also seen that due to the continuous technical developments, the technical terms are changing and growing almost daily. But how can we track and follow this process, especially in different languages?

As we have seen, producing a printed glossary makes almost no sense. We must then think in terms of online publications and platforms. To use different languages, a wiki, a collaborative website, may be the easiest and most practical form. A wiki can be edited by anyone who has access to it. To give an example, one of the most well-known wikis is Wikipedia. ${ }^{23}$ After doing a short research on Wikipedia, I found out that the following related glossaries have been created on it: "Glossary of jazz and popular music" (exists in English, Slovenian and Korean); "Glossary of musical terminology" (exists in 28 languages, but not in Hungarian), ${ }^{25}$ "Glossary of electrical and electronics engineering" (exists in

\footnotetext{
${ }^{21}$ https://de.schott-music.com/shop/lexikon-musikelektronik-no88735.html (accessed 10 May 2018).

22 Ibid. translated from German.

23 https://www.wikipedia.org (accessed 8 May 2018).

24 https://en.wikipedia.org/wiki/Glossary_of_jazz_and_popular_music (accessed 10 May 2018).

25 https://en.wikipedia.org/wiki/Glossary_of_musical_terminology (accessed 18 May 2018).
} 
English and Italian), ${ }^{26}$ additionally, only in German we find "Liste von AudioFachbegriffen." ${ }^{27}$ But as we take a closer look at these lists, none of them is a glossary of electronic (dance) music exclusively - it is completely missing from the platform.

Of course, a wiki also has its disadvantages: one cannot 'control' the participants of the project, so the entries could, for instance, be written unprofessionally. But on the other hand, if the community worked well, these kinds of elements could easily be corrected or filtered out. In other words, it can examine the content and quality of entries. The question would be, who can or should be part of this community? In my opinion, it should be open to anyone from the discourse community of electronic dance music. A more crucial point may be that the editorial community should include professionals, e.g. musicians, researchers (linguists and musicologists), related software and hardware developers.

I imagine this wiki as a multi-lingual platform that could help practitioners to keep track of new technical terms and eliminate translation problems in different languages. Of course, to plan such a glossary, one must research further into the terminology as a whole, and the preparation of the platform must also be well-planned.

\section{Conclusion}

As mentioned, this paper aimed at giving a general overview of the terminology and related phenomena of electronic (dance) music. To illustrate the topic in question, we have seen many different examples of the language use, and especially the terminology use of the discourse community of electronic dance music.

After classifying the terminology and analysing the actual situation of the glossaries, the most striking phenomena could be highlighted as follows: 1) the terminology of electronic (dance) music is not standardised, causing communicational and translational problems among the terminology users. This phenomenon can mostly be tracked in other languages than English; 2) English as a lingua franca

\footnotetext{
26 https://en.wikipedia.org/wiki/Glossary_of_electrical_and_electronics_engineering (accessed 10 May 2018).

27 https://de.wikipedia.org/wiki/Liste_von_Audio-Fachbegriffen (accessed 11 May 2018).
} 
has a leading position in the creation of new terms, which has an impact on other languages; 3) there are only a few glossaries of electronic (dance) music that are mostly not up-to-date anymore as the technological developments are faster than the production cycle of such publications; 4) as a result of these shortcomings, there are no standard sources that could be used by the terminology users, for example, if they want to translate or write an article (journalistic or academic) on the subject.

From these results we can see that there are a lot of different issues to discuss and solve in this field. Therefore, the paper also proposed a possible solution: a wiki on the subject in different languages. This stays on the level of an idea at the moment, but the author of this article will try to work on a detailed plan that can be used later for the preparation of an actual project.

I must also add that this article described its subject relatively briefly and it is only the beginning of a more detailed research. Its aim was to inform its readers about the most pressing problems and issues, and to draw attention to the gap in terminology research as described above.

\section{References:}

Ahland, Babs; Dreksler, Jacky; Härle, Quirin. 1988. Electronic Music ABC. Edition Metropol. Erftstadt.

CABré, M. TeresA. 1999. La terminología: representación y comunicación. Institut Universitari de Lingüística Aplicada, Universitat Pompeu Fabra. Barcelona.

CABré, M. Teresa. 2003. Theories of terminology. Their description, prescription and explanation. Terminology 9:2. 163-199.

Cabré, M. Teresa. 2009. La Teoría Comunicativa de la Terminología, una aproximación lingüística a los términos. Revue française de linguistique appliquée 14. 9-15.

Collins, Nick; Schedel, Margaret; Wilson, Scott. 2013. Electronic Music. Cambridge University Press. Cambridge.

CRYstAl, DAVID. 2001. Language and The Internet. Cambridge University Press. Cambridge.

Delaney, Martin. 2009. Ableton Live. Kezikönyv + tippek es trükkök a 6-os verzióhoz. Controllerbooks. Budapest.

Dobson, Richard. 1992. A Dictionary of Electronic and Computer Music Technology. Instruments, Terms, Techniques. Oxford University Press. Oxford - New York. 
Eimert, Herbert; Humpert, Hans Ulrich. 1973. Das Lexikon der elektronischen Musik. Gustav Bosse Verlag. Kassel.

Enders, Bernd. 1987. Lexikon Musikelektronik. Piper. Munich.

FóRIs, ÁGOTA. 2005. Hat terminológiai lecke. Lexikográfiai Kiadó. Pécs.

Fóris, ÁGota. 2010. A szaknyelvkutatás modelljei és módszerei: szociolingvisztikai megközelítés. Magyar nyelv 106/4. 424-439.

Herring, SusAn. C. 2004. Computer-mediated discourse analysis: An approach to researching online behavior. Designing for virtual communities in the service of learning. EDS. Barab, Sasha; Kling, Rob; Gray, James H. Cambridge Univer sit y Pr ess. Cambridge New York. 338-376.

Johnson, Mark. 1987. The Body in the Mind. The University of Chicago Press. Chicago - London.

JóRI, ANiTA. 2011. Az elektronikus zene szaknyelve és az internet. A pszicholingvisztikától a beszéd-technológiáig. Tanulmányok az alkalmazott nyelvészet hagyományos és új témaköreiből. Eds. Kiss, Zoltán; Ladányi, Mária; Petykó, Márton. Tinta Könyvkiadó. Budapest. 59-66.

JÓRI, ANITA. 2012. On the discourse community of electronic music.

http://www.soundstudieslab.org/on-the-discourse-community-of-electronic-music/ (accessed 6 May 2018).

JóRI, AnitA. 2013a. "A Facebook, a MySpace vagy a Last.fm? Hol attendingoljam magam az eseményre?” Avagy a közösségi portálok nyelvhasználata. Az interkulturális kommunikáció elmélete és gyakorlata. Eds. Gecső, Tamás; Sárdi, Csilla. Tinta Könyvkiadó. Budapest. 127-132.

JóRI, AniTA. 2013b. Kihívások az elektronikus zene szaknyelvében. Tudomány, technolektus, terminológia. A tudományok, szakmák nyelve. Eds. Veszelszki, Ágnes; Lengyel, Klára. Éghajlat Könyvkiadó. Budapest. 335-344.

JóRI, ANITA. 2015. A metaforikus nyelvi kifejezések vizsgálata a "funkkal szaggatott androidtechno" területén. Világ és nyelv szenvédellyel. Eds. Jóri, Anita; Folmeg, Márta. Tinta könyviadó. Budapest. 288-297.

JóRI, ANITA. 2016. On the discourse community of electronic dance music. Doctoral dissertation. Faculty of Humanities, Eötvös Loránd University. Budapest.

Lakoff, George. 1987. Women, Fire and Dangerous Things. University of Chicago Press. Chicago.

McLeod, Kembrew. 2001. Genres, Subgenres, Sub-Subgenres and More: Musical and Social Differentiation Within Electronic/Dance Music Communities. Journal of Popular Music Studies 13. 59-75.

Petersen, George; Oppenheimer, Steve. 1993. Tech Terms. A Practical dictionary for Audio and Music Production. EMBooks. Emeryville, CA. 
Rodgers, Tara. 2010. Pink Noises: Women on Electronic Music and Sound. Duke University Press. Durham, NC.

Shadow Producers. 2017. Good Musician: The biggest glossary of all music production words, acoustics terms, EDM genres, audio engineering terminology, recording vocabulary, and music theory definitions. Shadow Producers.

Swales, John. 1990. Genre Analysis. English in Academic and Research Settings. Cambridge University Press. Cambridge.

Temmerman, Rita. 2000. Towards new ways of terminology description: the sociocognitive-approach. John Benjamins. Amsterdam - Philadelphia.

\section{O nazivlju elektroničke glazbe}

\section{Sažetak}

Zahvaljujući brzomu tehnološkom razvoju, nazivlje elektroničke (plesne) glazbe neprestano se razvija. To također stvara izazove diskursnoj zajednici elektroničke plesne glazbe što se tiče upotrebe različitih tehničkih naziva. S obzirom na to da je prvo takvo istraživanje, ovaj rad daje opći pregled teme. U prvom se redu sažimaju značajke jezične upotrebe konkretne diskursne zajednice, zatim se naglašavaju različiti tipovi tehničkih naziva koje upotrebljavaju korisnici. U tu su svrhu podrobno analizirani tehnički nazivi iz rasprave na jednom internetskom forumu. Rad također opisuje neke od izazova u upotrebi tih tehničkih naziva time što navodi različite primjere iz triju jezika: engleskoga, njemačkoga i mađarskoga. Jezični fenomeni kao nedostatak standardizacije, normi i glazbenih glosara te utjecaj drugih nazivlja (npr. iz klasične glazbe, informatike, matematike i fizike) također su uključeni u istraživanje. Nakon što su iznesena najupečatljivija pitanja, u radu se predlažu i moguća praktična rješenja za navedene nedostatke: iznosi se plan za stvaranje platforme u wiki-formatu koja bi bila posvećena tehničkim nazivima u elektronskoj (plesnoj) glazbi.

Keywords: electronic dance music, discourse community, terminology, tech terms, standardisation, translation

Ključne riječi: elektronička plesna glazba, diskursna zajednica, nazivlje, tehnički nazivi, standardizacija, prevođenje 


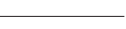

